\title{
Techno-Economic Analysis for Fertilizer House Using Hybrid Power Stations
}

Shiv Prakash Bihari ( $\sim$ spbiharinit@gmail.com )

Indian School of Mines

Pradip Kumar Sadhu

Indian Institute of Technology

\section{Research Article}

Keywords: Techno-Economic Analysis, Renewable Energy, Hybrid Power Stations

Posted Date: November 22nd, 2021

DOI: https://doi.org/10.21203/rs.3.rs-1079677/v1

License: (9) This work is licensed under a Creative Commons Attribution 4.0 International License. Read Full License

Version of Record: A version of this preprint was published at Soft Computing on February 7th, 2022. See the published version at https://doi.org/10.1007/s00500-022-06731-7. 


\title{
TECHNO-ECONOMIC ANALYSIS FOR FERTILIZER HOUSE USING HYBRID POWER STATIONS
}

\begin{abstract}
Renewable energy sources are not necessarily declining carbon sources. A hybrid generation network may be used in the power market to maximize the usage of renewable energy sources. The aim is to model hybrid power station and to determine the most effective system design through cost estimation. The power consumption of an agricultural device illustrates fertilizer house electricity needs and agricultural land irrigated pumps providing an average of $165.44 \mathrm{kWh} / \mathrm{h}$ of electricity per hour, an overall energy use of $7.12 \mathrm{~kW}$ and a total load of operation of $19.57 \mathrm{~kW}$. The standard radiation intensity is $5.35 \mathrm{kWh}$ per $\mathrm{m}^{2}$ per day, the luminosity amount is an around 0.534, and the maximum wind velocity is $4.60 \mathrm{~m} / \mathrm{s}$. Electricity generation is $\$ 323,659.25$ and the gross electricity expense $\left(\mathrm{Co}_{2}\right)$ is $\$ 1,325$ and reflects an annual monthly power consumption of 21,264 kWh (47.1\%) and 12,756 kWh/yr (36.8\%).

Index - Techno-Economic Analysis, Renewable Energy; Hybrid Power Stations;

\section{Introduction}

Renewable sources of energies are not necessarily declining carbon sources. Renewable energy originates in vast amounts from natural resources on the planet such as the air, wind, lakes, rivers, plants etc.[1].

A Hybrid grid $(\mathrm{HG})$ is a distribution electrical network that facilitate the penetration of different local generation sources, with or without storage devices [1]. For reliability and economic purposes, a HG can include Renewable Energy Source (RES), 
conventional generators, storage devices and consumption loads. A HG can operate in both Grid-Connected (GC) mode and isolated mode. In GC mode, the HG is linked to the main grid through a point of common coupling, and an energy trading can be benefit by receiving or sending energy with the grid as consumer or vendor.

In view of the challenges to renewable energy expansion, hybrid renewable energy (HRE) is considered of most significance in upcoming days for power generation systems (PGSs). Even as its research continues technologically and economically, HRE PGSs have shown internationally recognized environmental and social benefits. The non-consistent output power for a standalone power generation systems contribution between several options are highly likely to be PV-WP generation systems. Netconnected hybrids have a large potential. The optimal design of these systems requires care, requiring trade-offs between decision-making criteria to improve sustained energy development. Technical literature is rich in proposals on methods for optimizing the size of hybrid PGS. Specific techniques have in the past been used on various methods. The new program will provide a unique technological performance [4]-[10]. PSO [1], genetic algorithms [2] and [3], non-linear, mixed integer programme [4], dualsimulation annealing-tabu search algorithms [5] and specific prospects for dual GMP price optimisation. A certain target feature is assumed in general to be reduced, which mainly is the overall cost of the system; certain technological and environmental criteria may be incorporated in the sizing phase in two schemes: firstly, considering the necessities as restrictions and, secondly, the transfer of the additional method. Therefore, the ultimate judgment on both methods is similarly relevant to all system requirements / variables. With the aid of a Multi-Objective PSO or genetics algorithm the Pareto system is considered to be a great solution collection in [11] and [12] at the 
same time to boost objective functions (environment, economic or technical). Thus these methods provide the best solution for different PV-WP configurations, thus leaving the decision maker's final choice, which may not be a simple task. In addition, all the parameters in this case are equally relevant. Essence, the right hybrid PV-WP method, a big balance of various parameters in design, contributes to a suboptimal solution cannot be derived from the solutions that are already proposed. The particle swarm optimization (PSO) algorithm was used for optimal location and tuning of a new custom power device (CPD) for minimization of the total CPD injected currents and the total harmonic distortion (THD) of current and voltage. Hence, the real-time control of reactive power with CPD was suggested. The hybrid approach incorporates a variety of generation technologies from both renewable and fossil-based sources [2],[3]. Usage of the dual generation network will be a way to improve and have a potential benefit for the usage of renewable energy in the power segment [4].

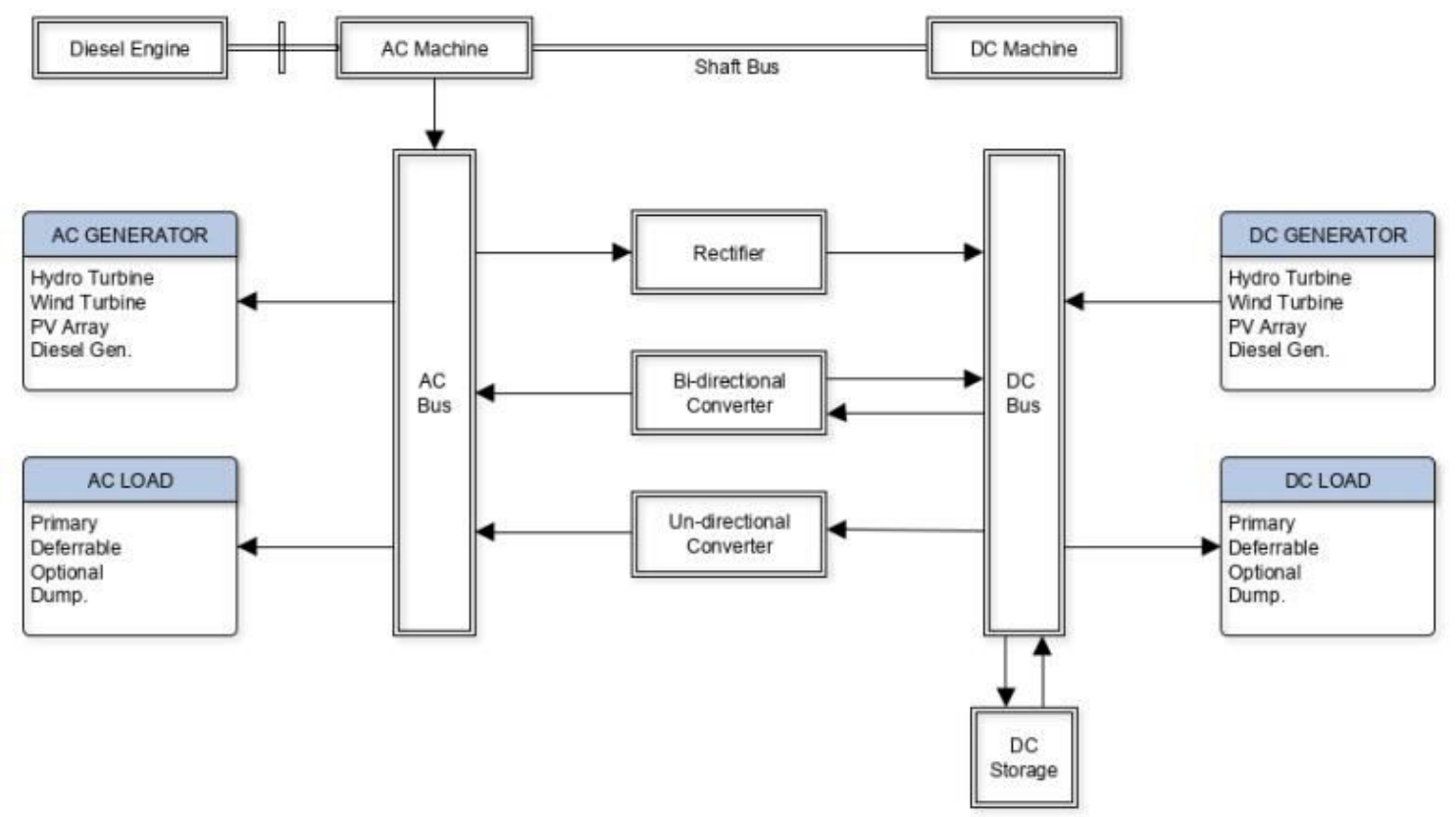

Fig. 1. Methodology of Hybrid Power Generation Systems. 
The usage of electricity on a area involves composting houses and pumping activities with a minimum of around $21.4 \mathrm{~kW}$ for irrigation and other specifications.

\subsection{Wind and Solar hybrid power generation system}

Hybrid power production combines PV, wind power, pump, inverter and control [4]. A hybrid network has been developed with device load, loading of the battery and loading the safety system (system load) [6].

\subsection{Deployment of PV Energy}

Photovoltaic (PV) technology turns the produced lunar energy into one of the world's greatest origin of electricity. Such photovoltaic system is one of the technologies most mature such that it is a future-oriented product [6],[7].

When operating, solar cell apparatus like PV modules, converters, inverters, cables, transformers and additional apparatus must be arranged according to their supporting component [9]. The usage of solar power technologies is split down into grid networks and off-grid technologies. The electricity expended on battery storage in off-grid systems [7],[9].

Silicium has grown well as a key substance for PV panels. The use of silicon as a raw material in the manufacture of solar panels is shown by the advancement of the technologies that follows and by the availability of silicon. Silicone types have been identified as mono-c-Si, poly-c-Si and EFG ripple silicone [9],[7],[7], respectively c-Si. Silicone is a type of mono-c-Si.

PV modules must be designed for the usage of the photovoltaic system in a power station design. Such photovoltaic modules are attached to help apparatus like batteries, inverters, wires, converters and other associated devices [10]. Therefore, with an off- 
grid system [7],[9],[11] in the system for solar electricity which needs the use of batteries is suitable.

\subsection{Efficiencies of photovoltaic Modules}

The efficiency of PV cell component is illustrated by the photovoltaic material's physical properties, as the PV cell soak up heat from the daylight, then converted into electrical power. The PV module function factor is presented in the next equation [6]:

$$
P_{m}=-\left(p D_{t t}+q\right)\left(T_{u}+0.03375 D_{t t}\right)+r D_{t t}+s
$$

Where $\mathrm{D}_{\mathrm{tt}}$ is the power consumed by PV cells as a least amount solar radiation, W / $\mathrm{m}^{2} ; \mathrm{T}_{\mathrm{u}}$ is the available temperature across PV cells, $\mathrm{K}$; and $\mathrm{p}, \mathrm{q}, \mathrm{r}$ and $\mathrm{s}$ is a constant in the PV regression.

\subsection{Arrangement of PV cells}

In real life uses, the PV module is required to manufacture a mixture of PV-solar modules. The system for PV module may be series and parallel based on the requirements when the pressure of the DC decreases or output. The following equation indicates the solar cell unit voltage [4]:

$$
V_{P V}=N_{P V} \cdot V_{P V}
$$

Also the output power $\mathrm{P}_{\mathrm{PVA}}$ of the PV cell is:

$$
P_{P V}=N_{P V} \cdot N_{P V} \cdot V_{P V} \cdot J_{c o n} \cdot J_{o t h}
$$

Where $\mathrm{N}_{\mathrm{PV}}$ is a sequential PV link number; $\mathrm{N}_{\mathrm{PV}}$ is the parallel PV module strings link number; $\mathrm{J}_{\mathrm{con}}$ and $\mathrm{J}_{\mathrm{oth}}$ are the variables that cause contact losses and other damages, such as loss triggered by accumulation of other module particles.

\subsection{Inclusion of Radiation by PV Cells}

The sum of sunbeams that can be provided by the PV panels is the cause that produce electric power. In reality, the data of the calculated or observed sunlight 
intensity on a weather can only give the energy taken by the PV cell for the flat circumstance but the orientation of the installation of the PV panel given a twisted angle to maximize its values [7]. The model from Perez:

$$
\begin{gathered}
\xi=\frac{\left[\left(X_{y u}+X_{t u}\right) / X_{y u}+1.041 \varphi_{z}^{2}\right]}{\left[1+1.041 \varphi_{z}^{2}\right]} \\
\Lambda \equiv \frac{X_{y u} \cdot m}{X_{o n}}=\frac{X_{y u} \cdot m}{X_{0} / \cos \phi_{z}}=\frac{X_{y u}}{X_{0}}
\end{gathered}
$$

Where $\mathrm{m}$ is the mass of air.

The beam suppression coefficient $\mathrm{y}$ and $\mathrm{u}$ is the visibility coefficient, $\mathrm{X}_{1}$ and $\mathrm{X}_{2}$, are the features galaxy illumination correspondingly. The relation is subjected to as the Perez factor and its usage is shown in table 1.

$$
\begin{aligned}
P_{1}=P_{11}(\xi)+P_{12}(\xi) \Delta+P_{13}(\xi) \varphi_{z} \\
P_{2}=P_{21}(\xi)+P_{22}(\xi) \Delta+P_{23}(\xi) \phi_{z}
\end{aligned}
$$

The angular position of the whole solar circumference is finding by the ratio:

$$
\frac{d}{e}=\frac{\operatorname{peak}[0, \cos \theta]}{\text { peak }\left[\cos 45, \cos \theta_{z}\right]}
$$

After that the diffused radiation on the inclined plane can be determined by:

$$
X_{d t}=X_{y u} \cdot \cos ^{2}\left(\frac{\beta}{2}\right)\left(1-P_{1}\right)+X_{y u} \cdot P_{1} \cdot\left(\frac{d}{e}\right)+X_{y u} \cdot P_{2} \cdot \sin \beta
$$

Table 1. The parameters of Perez model

\begin{tabular}{ccccccc}
\hline$\varepsilon$ & $\mathrm{F}_{11}$ & $\mathrm{~F}_{12}$ & $\mathrm{~F}_{13}$ & $\mathrm{~F}_{21}$ & $\mathrm{~F}_{22}$ & $\mathrm{~F}_{23}$ \\
\hline $1-1.065$ & -0.008 & 0.588 & -0.062 & -0.060 & 0.072 & -0.022 \\
$1.065-1.23$ & 0.130 & 0.683 & -0.151 & -0.019 & 0.066 & -0.029 \\
$1.23-1.5$ & 0.330 & 0.487 & -0.221 & 0.055 & -0.064 & -0.026 \\
$1.5-1.95$ & 0.568 & 0.187 & -0.295 & 0.109 & -0.152 & -0.014 \\
$1.95-2.8$ & -0.873 & -0.392 & -0.362 & 0.226 & -0.462 & 0.001 \\
\hline
\end{tabular}




\begin{tabular}{ccccccc}
\hline $2.8-4.5$ & 1.132 & -1.237 & -0.412 & 0.288 & -0.823 & 0.056 \\
$4.5-6.2$ & 1.060 & -1.600 & -0.359 & 0.264 & -1.127 & 0.131 \\
$6.2-$ & 0.678 & -0.327 & -0.250 & 0.156 & -1.377 & 0.251 \\
\hline
\end{tabular}

\subsection{Wind Turbine Conversion System}

The power produced by the wind turbines is influenced by many factors. Factors affecting the output capacity include aerodynamic performance efficiency, mechanical transfer $\mu \mathrm{m}$ and electric energy conversion efficiency $\mu \mathrm{g}[12]$. In addition, the wind turbine's efficiency depends often on the state of the wind turbine field and the elevation of the center showing the generator location towards the ground floor [5].

The measurement effects of the wind turbine installed are described by:

$$
P_{w}\left(W_{v}\right)=\left\{\begin{array}{cc}
P_{w} \frac{V_{v}^{2}-V_{d}^{2}}{V_{n}^{2}-V_{d}^{2}} ; & V_{d} \leq V_{v} \leq V_{n} \\
P_{w ;} & V_{n} \leq V_{v} \leq V_{c} \\
0 ; & V_{v} \leq V_{d} \text { and } V_{v \geq V_{c}}
\end{array}\right.
$$

Where, $\mathrm{Pw}$ is wind output power, $\mathrm{Vd}$ is reduced wind speed, $\mathrm{Vn}$ is standard wind speed and $\mathrm{Vv}$ is velocity of wind.

The wind speed system had a significant effect on the strength of the generated wind turbine. The vertical profiled speed of wind in a horizontal homogenous environment, like desert, grassland, plane field and other areas is strongly defined by this wind speed profile. The equation shown below provides the fundamental outline of the wind speed perpendicularly [5]:

$$
\frac{v}{v_{d}}=\left(\frac{e}{e_{r}}\right)^{k}
$$

where $\mathrm{v}$ is the wind velocity of center e $\mathrm{m} / \mathrm{s}, \mathrm{v}_{\mathrm{d}}$ is speed of the wind comparison $\mathrm{e}_{\mathrm{r}}, \mathrm{m} /$ $\mathrm{s}$; alpha is a model of the power rule.

\subsection{Optimized Model for Renewable Energy using MATLAB}


The Hybrid Optimization Model for renewable energy developed in (MATLAB) software created for the design and comparison of power generation technologies by the U.S. National Renewable Energy Laboratory (NREL)[2][3] and [13], developed in the United States. MATLAB models reflect the physical comportment and total cost power of the device, which includes overall deployment and cost of operation [14].

Past research presented findings and assumptions about the MATLAB model in hybrid device development[1]-[3],[15],[16], respectively.

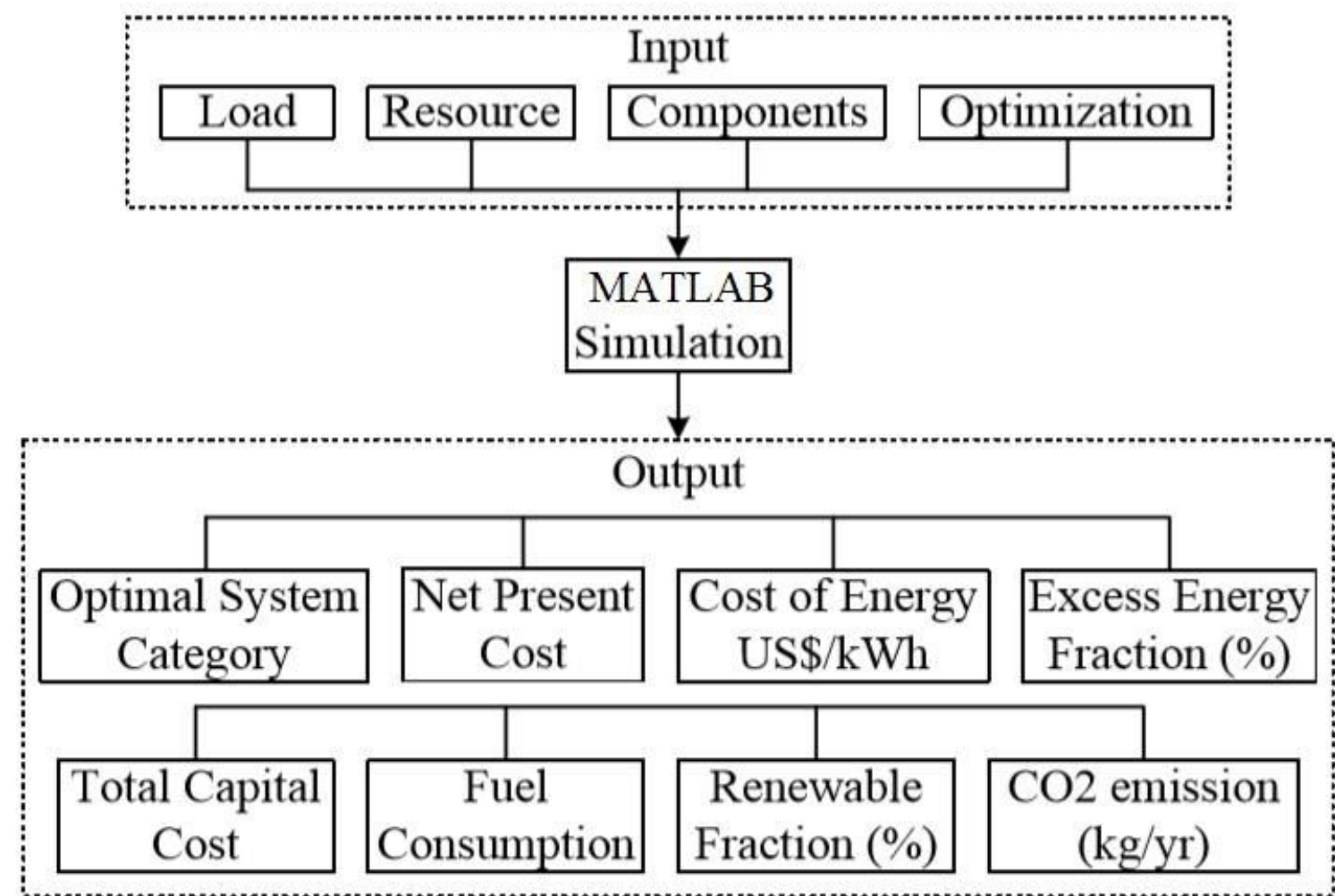

Fig. 2. optimization of MATLAB program [13].

The goal of this analysis is to model hybrid systems and to decide, according to cost estimates, the best device configuration.

\section{RESEARCH TECHNIQUES}

\subsection{Power load}


In addition, the demand for electric power is not so strong in farm land contrasted with the need for electric power both in industrial and rural areas in the residential sector. Power requirement in the fertilizer house and the power needed for irrigation pumps in the agricultural area are the requirements for electric power which have to fulfill in an agricultural sector. Figs. 3 and 4 display regular and monthly demands for electricity.

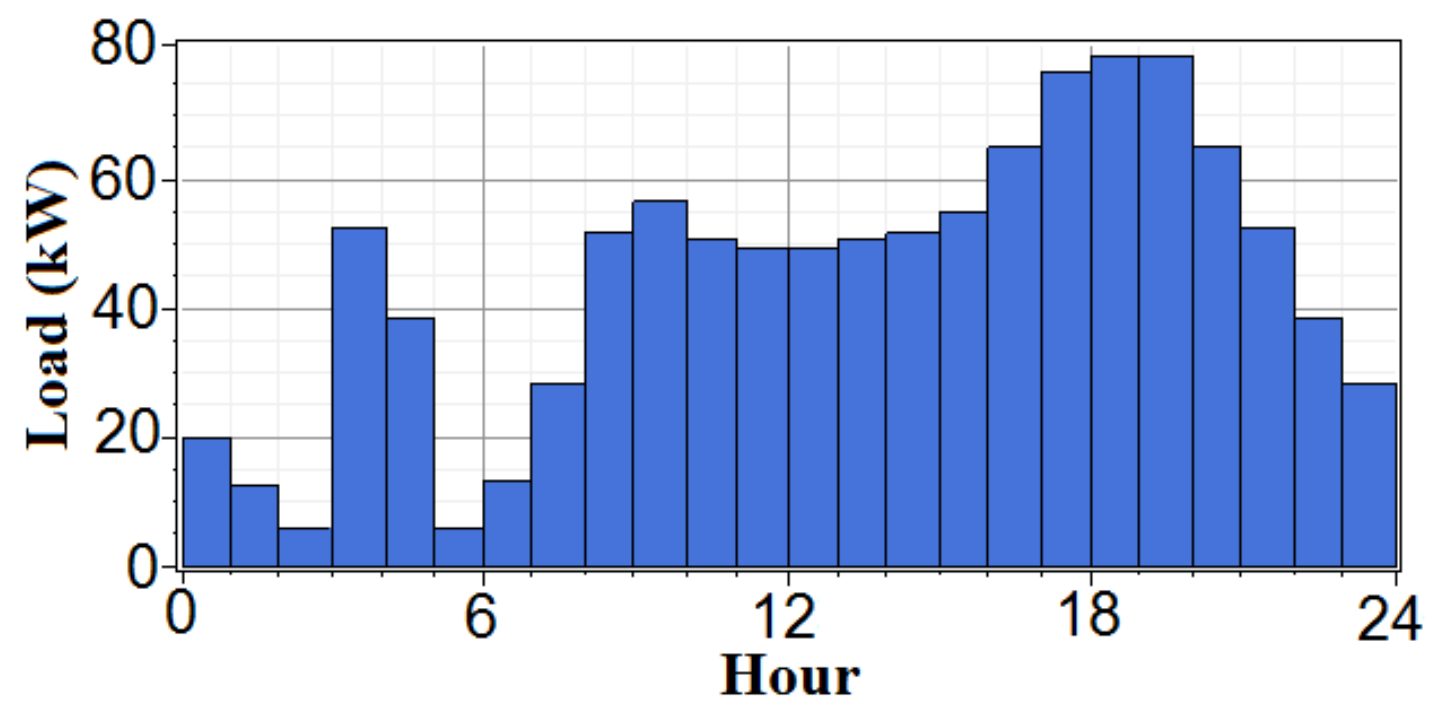

Fig. 3. Status of daily load data.

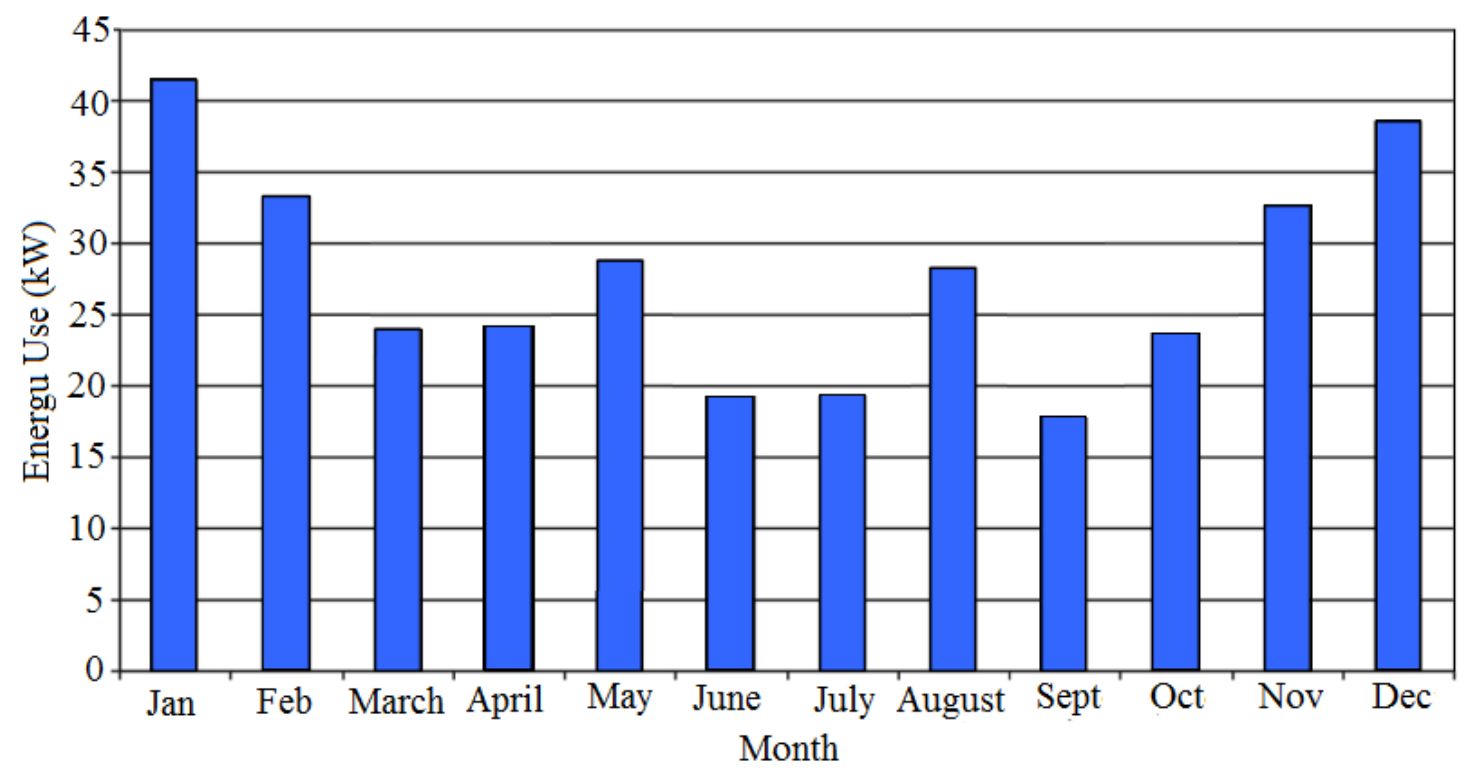

Fig.4. Status of load demand per month. 
The total power usage in the hour is $165.44 \mathrm{kWh} /$ day, the total energy requires in the university farm are $6.89 \mathrm{~kW}$ and the highest electricity use during use is $20.46 \mathrm{~kW}$, seen in Fig.5. Based on a one-year usage model, the utilization of electrical resources in the farm unit at 7 a.m. indicated that all equipment, such as watering pumps and sprinkles and water deliveries to agriculture, were operationally efficient at that period.

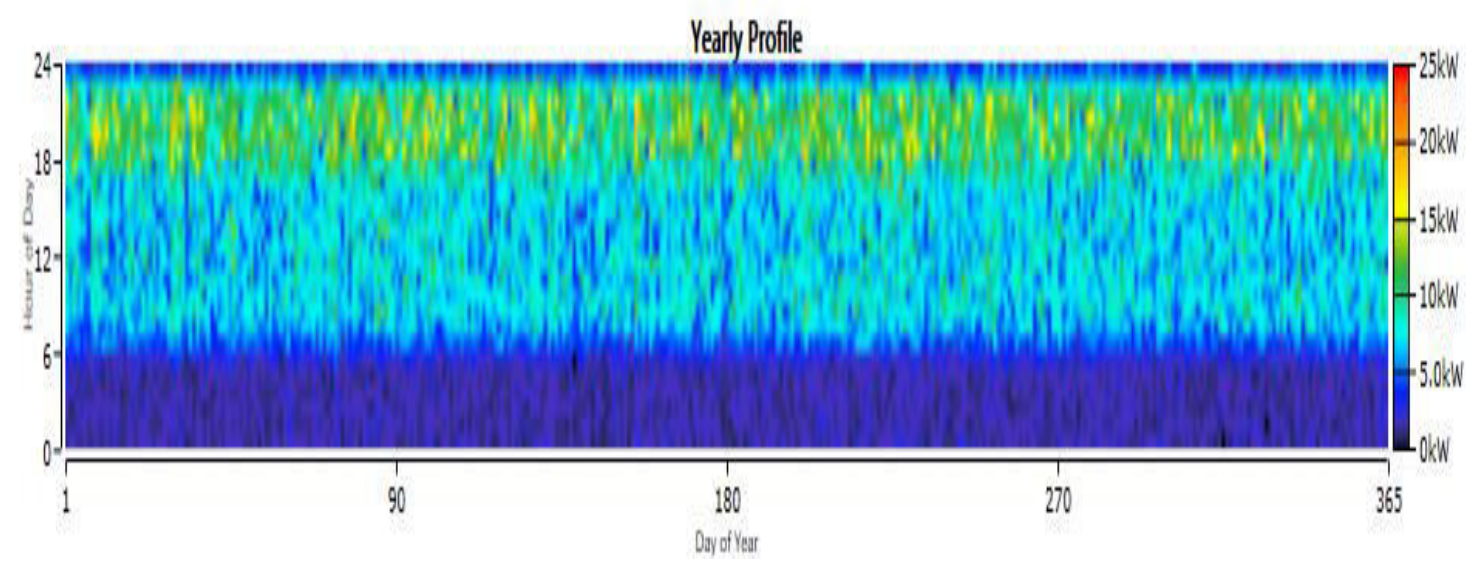

Fig.5. Average load data for whole year

\subsubsection{Solar Irradiance available across the earth}

The solar irradiance schemes provides normal radiation details at the research site for one year. The study also displays the sunlight index norm with information regarding the surplus of solar energy on the surface of the planet and shifts in the atmosphere[16]. Fig.6 indicates an overall 5,980 W/ $\mathrm{m} 2$ / radiation day and a radiation source of $3,870 \mathrm{~W} / \mathrm{m}^{2} /$ day and a lower radiation amount of $2,380 \mathrm{~W} / \mathrm{m}^{2} /$ day is recorded in February and $5380 \mathrm{~W} / \mathrm{m} 2$ / day in November. The maximum ranking for sunlight is 0,472 , for February it is 0,513 and for October it is 0,433 . The lowest. The value is high of 0.434 . The data indicate a linear connection between the overall sum of sunlight and the lightness of the same month. 


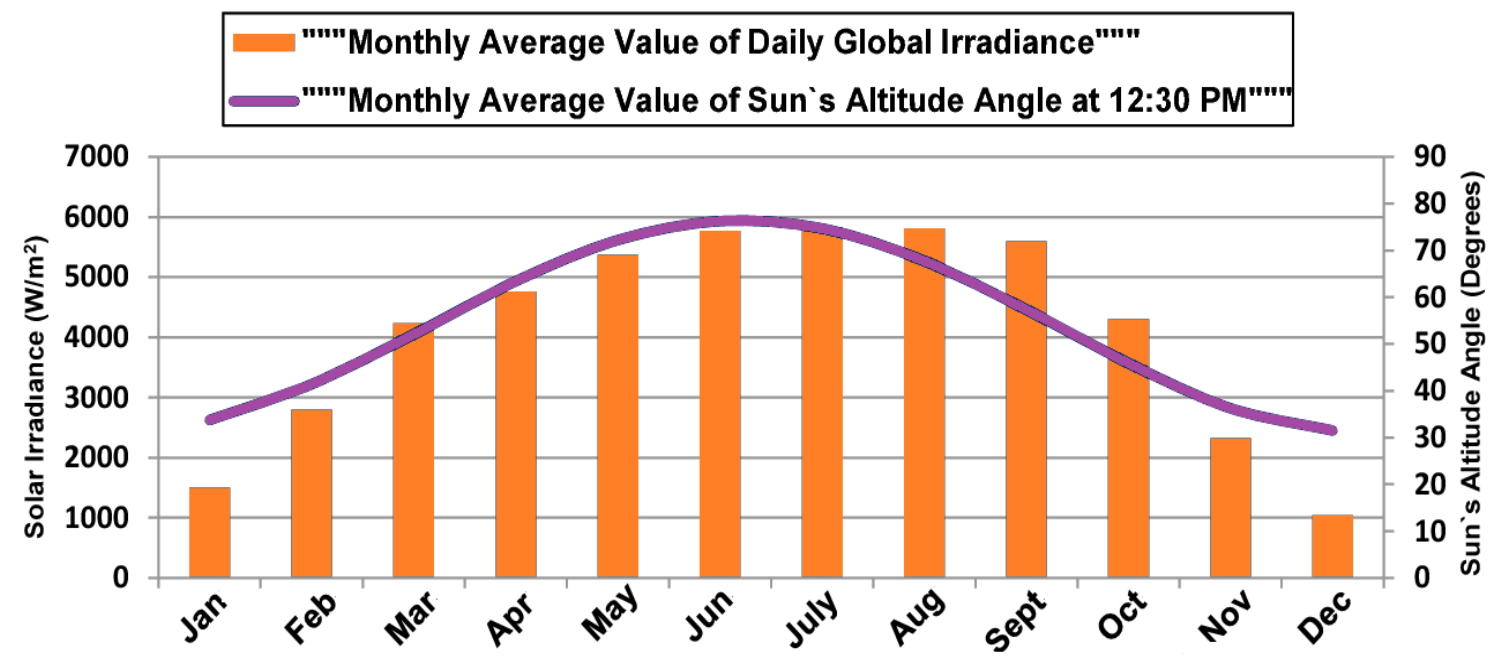

Fig.6. International average results of solar in horizontal plane.

\subsubsection{Wind Sources}

The monthly forecasts of the wind speed over a year show. The statistics in Fig.7 indicate that the wind speed limit is $3.30 \mathrm{~m} / \mathrm{s}$. The highest wind speed is $3930 \mathrm{~m}$ per second in August and the lowest wind speed is $3380 \mathrm{~m}$ per second in March. Air speed scale 0 meters above sea level and a reference point 50 meters above sea level. For the wind speed trend a linear meaning of wind strength varies between $0.01 \mathrm{~m}[18]$ and surface ruggedness[19].

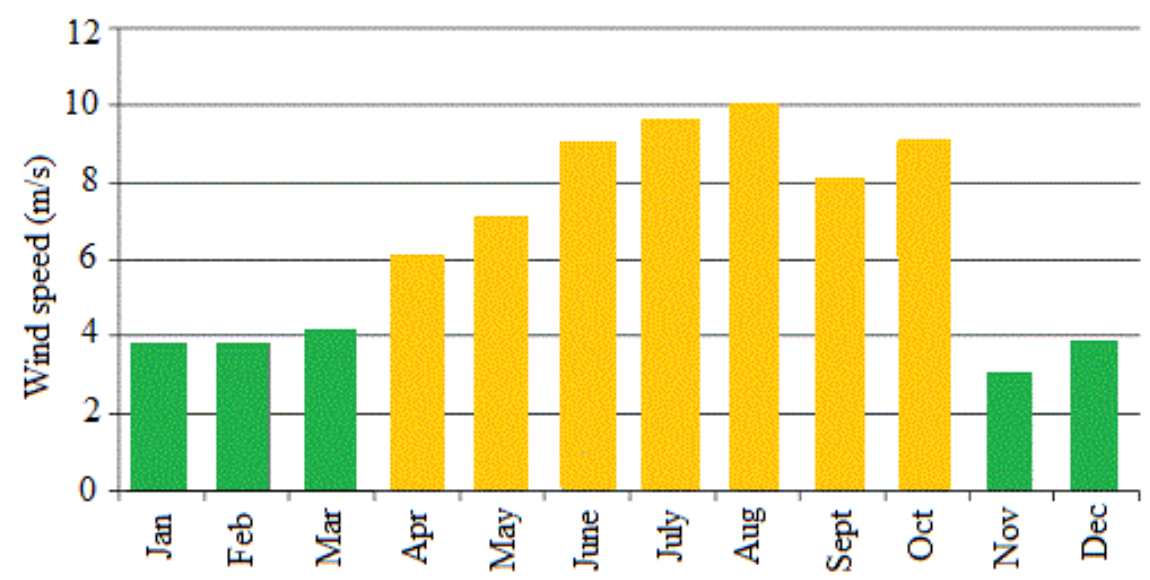

Fig.7. Base monthly wind velocity results

\subsubsection{Fuel sources}


The properties of the diesel fuel in Fig. 8 are seen in this study. The estimate reveals that $43,20 \mathrm{MJ} / \mathrm{kg}$ is the lowest fuel heating weight, $820 \mathrm{~kg} / \mathrm{m} 3$ is diesel fuel mass, $88 \%$ of fuel oil is gasoline, and $0,4 \%$ of fuel sulfide is jet petrol. Different factors equal to $\$ 0.7$ / $\mathrm{L}$ was liable at the time of these investigation for purchasing diesel fuel and rising inflation due to increased demand.

FUELS AVAILABLE IN MODEL

\begin{tabular}{|llllll|}
\hline Name & LHV & Density & Carbon & Sulfur & Special \\
\hline Diesel & 43.2 & 820 & 88 & 0.4 &
\end{tabular}

Fig.8. Specification of Fuel

\subsection{Parameters of hybrid system}

Fig.9 displays hybrid device elements composed of plane horizontal PV, wind generators, engines, batteries and converters. The hybrid device architecture demonstrates that the network has been design to accommodate non-run generation systems for wind generators, photovoltaic systems and generators. This hybrid network is intended to fulfill the enhancing power supply from renewables. If green power is not enough for the generation of electricity, turbines are used as backups for resources. In every segment of the hybrid system, the following is explained.

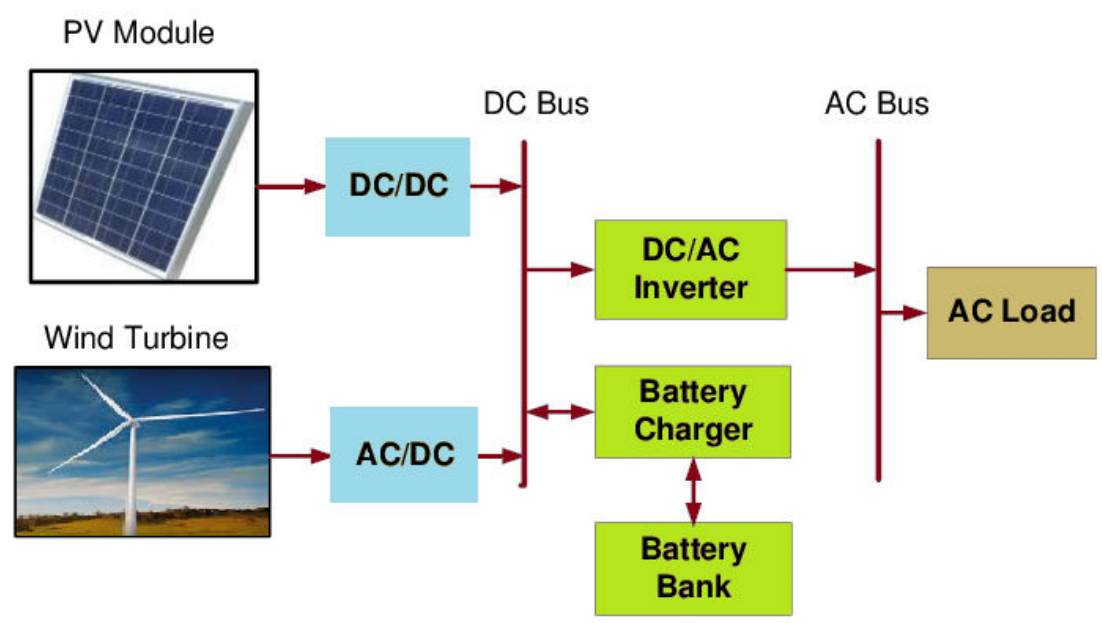


Fig. 9. Hybrid power generation system diagram

\subsubsection{Wind Generator}

The common model $1 \mathrm{~kW}$ wind turbine chosen in this analysis is $\mathrm{G} 1$ abbreviation with an output of $1 \mathrm{~kW}$. With a rate of $€ 7,000,00$, the expense of repairing the wind turbine after it has finished is $\$ 7,000.00$, so the running so repair benefit of the turbine is $\$ 140,00$ a year. The expense of removing the turbine after its expiry. The wind turbine runs for $20 \mathrm{yrs}$. and the length of the turbine pitch is $18 \mathrm{~m}$ long.

The wind power generator mounted transfers electricity to the wind speed of the wind turbine. Based on the air speed obtained and shown in Fig.10, the wind turbines produced electricity. It can be seen from the picture that the Typical $5 \mathrm{~kW}$-type wind generator has an rising strength at wind speeds of up to $9 \mathrm{~m} / \mathrm{s}$ and that the generator output decline at the speed of up to $15 \mathrm{~m} / \mathrm{s}$.

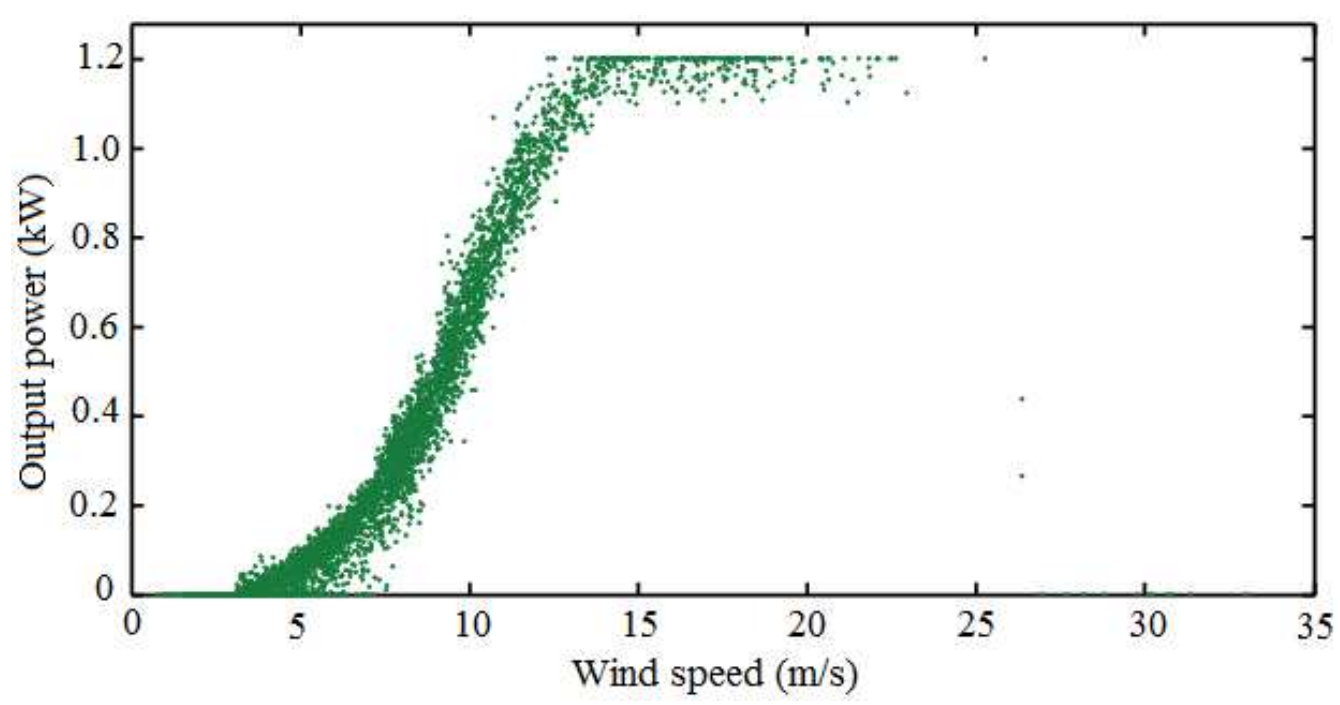

Fig.10. Energy curve of wind turbine

\subsubsection{PV Module}

Research includes a solar platform with wind mill and generators to fulfill electrical resource requirements in agriculture. Standard PV flat plate is named after the solar panel and the average production of $1 \mathrm{~kW}$ of solar panel, the construction cost is 
$\$ 3,000.00$ (Fig.11 indicates the costing curve for the building of solar panels in $\mathrm{kW}$ ) and with a maintenance expense of $\$ 10,00$ a year if the 25 year utilization cap of 12.00 is exceeded.

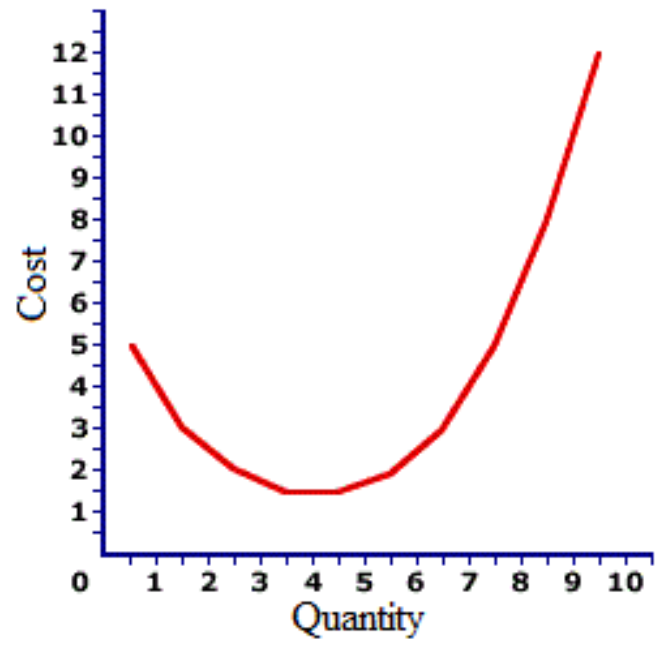

Fig.11. Cost Analysis

\subsubsection{Generator}

The analysis should have a power of $21.4 \mathrm{~kW}$ for the energy required in the university farm. Renewable energy production does not guarantee adequacy as solar panel systems do not produce power during the night and wind turbines' output is heavily contingent on the availability in the natural environment of wind energy. The electronic power generators used are mechanical fuel types, diesel fuel type and $\$ 0.7 \%$ of the quality which have characteristics such as minimum heating intensity $45.4 \mathrm{MJ} /$ $\mathrm{kg}, 820 \mathrm{~kg} / \mathrm{m} 3$ mass, $88 \%$ carbon content which $0.4 \%$ sulfur. The prices for $\$$ per $\mathrm{kW}$ of generators are $\$ 500.00$, the expense for repair while the running cycle is at $15,000.00$ and the prices for production and repairs are $\$ 0.030$. $\$ 500.00$.

\subsubsection{Storage batteries}

When the power flow cannot begin directly from the produced energy source, batteries must meet electricity requirements. The electricity generated by the wind 
turbines, solar panels and generators are provided by batteries. The form of battery in Table 2 for this analysis is standardized $1 \mathrm{kWh}$ NI-OH with a nominal $12 \mathrm{~V}$ voltage and a standard output of $2 \mathrm{kWh}$ and an overall stated capacity of 94.3 Ah battery. The total expense is $\$ 300.00$, the expense of maintenance for 10 years and the cost of service and rehabilitation of $\$ 20.00$ a year.

Table 2. Parameters for basic $1 \mathrm{kWh} \mathrm{Ni}-\mathrm{OH}$ battery

\begin{tabular}{lc}
\hline Standard Capacity & $2 \mathrm{~kW} \mathrm{~h}$ \\
Standard voltage & $15 \mathrm{~V}$ \\
Overall efficiency & $85 \%$ \\
Minimum SoC & $50 \%$ \\
Lifespan & $15 \mathrm{yrs}$ \\
Output power & $700.00 \mathrm{~kW} \mathrm{~h}$ \\
Highest rate of charge & $1.5 \mathrm{~A} / \mathrm{h}$ \\
Highest charging current & $14.6 \mathrm{~A}$ \\
\hline
\end{tabular}

\subsubsection{Converter}

As DC transducers that are generated in the form of $\mathrm{AC}$ power that renewables, a converter will be required. In order to do this analysis, the converter type utilized is a 2$\mathrm{kW}$ unit converter, with $\$ 300.00$ installation costs, which includes a $\$ 300.00$ service fee over 15 years.

\section{Results and analysis}

\section{1 study of complex cases}

A variation of variable response factor is used in susceptibility situations. As the importance of several wind speeds and other fuel price values are calculated, cases of vulnerability subtract each importance in conjunction with the amount of variations of each value. Homer would then refine all the responsiveness values reached. In the sensitivity study, when assessing the design of the device, the importance of the fuel price and maximum wind speed is taken into account. At $0,7 \$ / 1$ and average wind 
velocity at $3.30 \mathrm{~m}$ per square meter during network growth, the price of diesel fuel was. This research rate has a retail value of $\$ 0.35$ to $\$ 0.70$ to $\$ 1.40$. The wind speed differs from $\$ 3.00,3.30$ and $8.00 \mathrm{~m} / \mathrm{s}$, respectively. Fig.13 displays the sensitivity analysis figures, showing the instability of the growing factor of responsiveness in optimisation experiments, the amount of power created by each kind of device, for example, solar panels, wind turbines and generators. For this study, lowest power, operational and initial capital costs, and the maximum jet fuel reactivity levels are seen with the fuel price of $\$ 140 / \mathrm{L}$ with average wind speeds of $80.0 \mathrm{~km} / \mathrm{s}$ for comparison with $\$ 350 / 1$ diesel fuel and an average wind speed of $33.0 \mathrm{~m} / \mathrm{s}$.

The findings of this study are seen in a surface graph seen in Fig.13, showing that the $\mathrm{Y}$-axis reflects the average diesel fuel price $(\$ / \mathrm{L})$; the wind vector value $(\mathrm{m} / \mathrm{s})$ for the X-axis. A surface graph of the cost of electricity $(\mathrm{CoE})$ and the Net Present Cost (NPC) calculation is taken into account for the product evaluation.

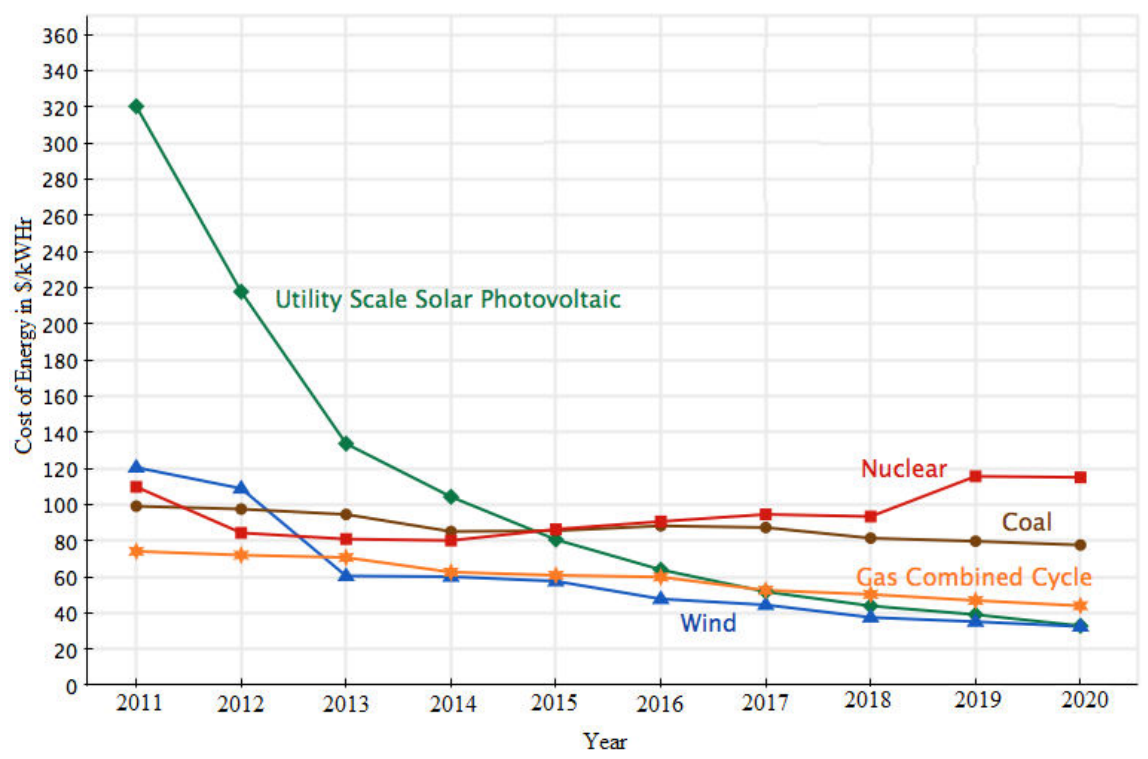

Fig.13. Sensitive analysis of Energy Cost per year

\subsection{Outcomes of Optimization}


For the device set-up with a sensitivity in diesel fuel rates of $\$ 70.0$ / L and an usual wind speed of $33.0 \mathrm{~m} / \mathrm{s}$, optimisation outcome shall be given. The outcomes of the development phase was focused on the lowest cumulative current (NPC) net expense of $\$ 211,894.30$ and energy costs of $\$ 0,424$. A $15,0 \mathrm{~kW}$ generator, $15,5 \mathrm{~kW}$ solar cell, a 15 string battery, a $7,83 \mathrm{~kW}$ converter, a system of charging of processes are created by designing multiple components.

The gross operating loss and fixed costs are seen in Fig. 16 represents the system optimization results respectively at $\$ 21,894$ and $\$ 16,576$. The study of budget overviews covers capital spending, operating expenses, depreciation, improvements and investment in real estate. The net present cost valuation of capital and operating expense for the fixed expenses needed a valuation of $34.75 \%$. This expense demonstrates that the cost of capital is a core asset and a foundation for device growth.

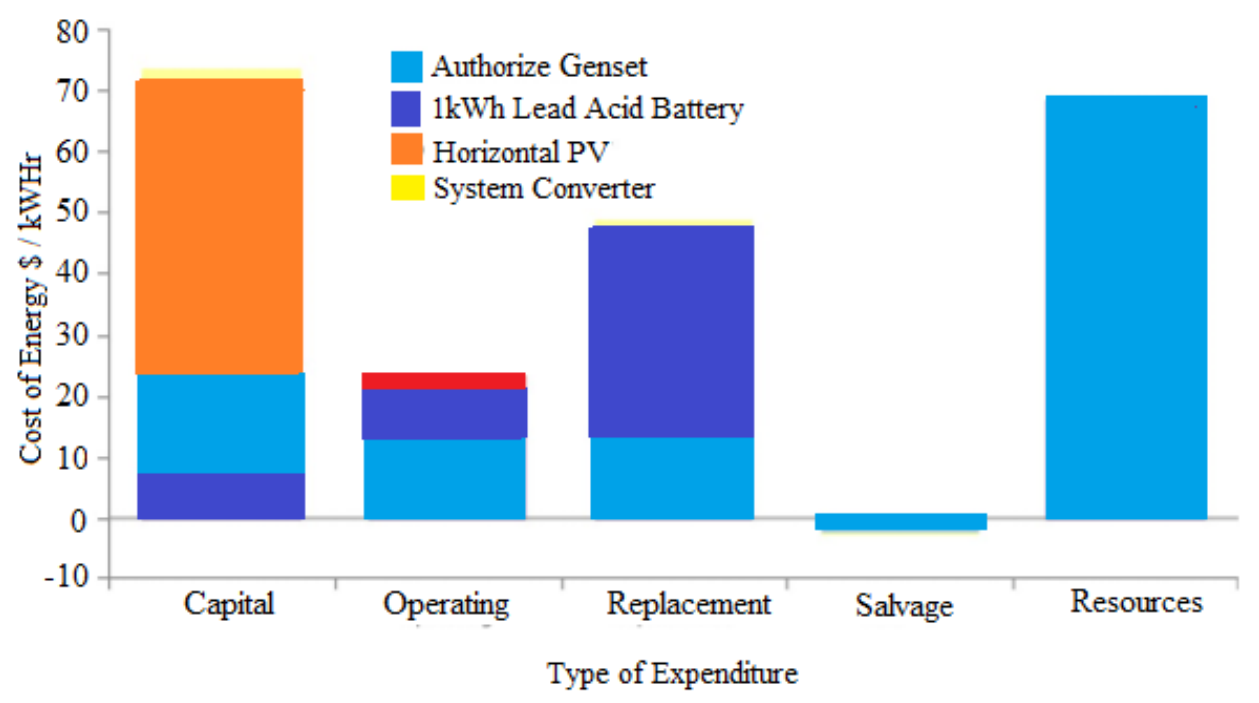

Fig. 16. Analysis of Energy cost and expenditure type

The estimated generation of electrical power per month is $20.436 \mathrm{kWh} /$ year and $22.745 \mathrm{kWh} / \mathrm{yr}$ per solar cell component and turbine. The color coding reveals the color orange, as the electricity generated in a pv module is $47.1 \%$ and the energy in a generator is $52.9 \%$, as seen in Fig. 17. The result indicates that energy supplied by the 
high-value turbine is compared to energy created by the solar cells throughout power generation. Annual AC power consumption at the University plant contributes to 39,055 $\mathrm{kWh} /$ year. The unit has produced $45,130 \mathrm{kWh} /$ year of electricity, and the energy surplus can be retained in the battery at $1.882 \mathrm{kWhr} /$ year or $4.17 \%$.

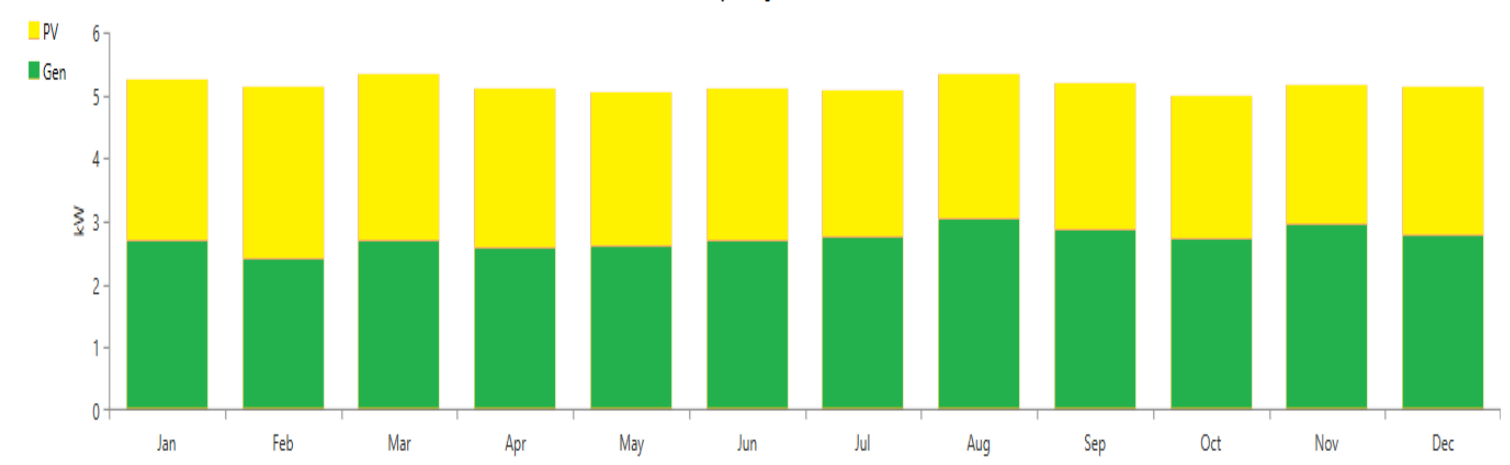

Fig.17. Power generation in every month

\section{CONCLUSIONS}

The aim of this analysis is to study the Hybrid Farm's energy fulfillment system and economic efficiency by simulating a hybrid power plant network and deciding on the optimal configuration and costs. The average power output per hour is $146.33 \mathrm{kWh} / \mathrm{d}$ per annum. The usual radiation is $4,71 \mathrm{kWh}$ per $\mathrm{m} 2$ per day. GHI Study records. In the sensitivity study, there are differences in the results of the sensitivity element, measuring the strength from different power plant types, such as solar panels, wind turbines or generators. The findings for improving the design of the system with a price sensitivity vector in diesel fuel of $3.30 \mathrm{~m}$ per s are $\$ 0.700$ per litre. The gross expense is $\$ 0,424$ and the cost of power is $\$ 0,424$, as a result of various components being combined, with the aggregate costs of a generator of $12.0 \mathrm{~kW}$, a pv module of $12.5 \mathrm{~kW}$, a $15 \mathrm{~V}$-line battery, a transformer of $7,83 \mathrm{~kW}$ and a loading process. The total electricity per month (47.1\%) and $23866 \mathrm{kWh} / \mathrm{yr}(52.9 \%)$ was provided by PV cells and power 
generators. The total production of the AC power farm is $39,055 \mathrm{kWh} /$ year and its machine generates $45,130 \mathrm{kWh} /$ year, which ensures it is capable of producing an additional $1,892 \mathrm{kWh} / \mathrm{yr}$ or $41.7 \%$ surplus electricity.

\section{References}

[1] H. Lund, "Renewable energy strategies for sustainable development," Energy, vol. 32, no. 6, pp. 912-919, 2007, doi: 10.1016/j.energy.2006.10.017.

[2] M. K. Shahzad, A. Zahid, T. Rashid, M. A. Rehan, M. Ali, and M. Ahmad, "Techno-economic feasibility analysis of a solar-biomass off grid system for the electrification of remote rural areas in Pakistan using HOMER software," Renew. Energy, vol. 106, pp. 264-273, 2017, doi: 10.1016/j.renene.2017.01.033.

[3] R. Sen and S. C. Bhattacharyya, "Off-grid electricity generation with renewable energy technologies inIndia: An application of HOMER,” Renew. Energy, 2014, doi: 10.1016/j.renene.2013.07.028.

[4] A. M. Patel and S. K. Singal, "Economic analysis of integrated renewable energy system for electrification of remote rural area having scattered population," Int. J. Renew. Energy Res., vol. 8, no. 1, pp. 523-539, 2018.

[5] H. Yang, L. Lu, and W. Zhou, "A novel optimization sizing model for hybrid solar-wind power generation system," Sol. Energy, vol. 81, no. 1, pp. 76-84, 2007, doi: 10.1016/j.solener.2006.06.010.

[6] “Technology Roadmap Solar photovoltaic energy," Current.

[7] R. Januar, "Comparative Analysis of 20-MW Solar Thermal and PV Power Plant in Rongkop, Indonesia Using LCOE Simulation Method,” J. Clean Energy Technol., vol. 5, no. 5, pp. 383388, 2017, doi: 10.18178/jocet.2017.5.5.402.

[8] H. S. Das, A. Dey, T. C. Wei, and A. H. M. Yatim, "Feasibility analysis of standalone PV/wind/battery hybrid energy system for rural Bangladesh," Int. J. Renew. Energy Res., vol. 6, no. 2, pp. 402-412, 2016.

[9] M. Mousa, V. R. Sagar, V. T. Gajbhiye, and R. Kumar, "Pesticides persistence in/on fresh and 
dehydrated brinjal,” J. Food Sci. Technol., vol. 41, no. 4, pp. 429-431, 2004.

[10] M. Kamran et al., "Designing and optimization of stand-alone hybrid renewable energy syKamran, M., Asghar, R., Mudassar, M., Ahmed, S. R., Fazal, M. R., Abid, M. I., ... Zameer, M. Z. (2018). Designing and optimization of stand-alone hybrid renewable energy system for rural a," Int. J. Renew. Energy Res., vol. 8, no. 4, 2018.

[11] S. Vergura and V. Lameira, "Technical-Financial Comparison Between a PV Plant and a CSP Plant,” Sist. Gestão, vol. 6, no. 2, pp. 210-220, 2011, doi: 10.7177/sg.2011.v6.n2.a9.

[12] A. Bouakkaz, S. Haddad, J. A. Martín-García, A. J. Gil-Mena, and R. Jiménez-Castañeda, “Optimal scheduling of household appliances in off-grid hybrid energy system using PSO algorithm for energy saving,” Int. J. Renew. Energy Res., vol. 9, no. 1, pp. 427-436, 2019.

[13] “HOMER 404.".

[14] E. C. Okonkwo, C. F. Okwose, and S. Abbasoglu, "Techno-economic analysis of the potential utilization of a hybrid PV-wind turbine system for commercial buildings in Jordan," Int. J. Renew. Energy Res., vol. 7, no. 2, pp. 908-914, 2017.

[15] S. Bai and K. V. S. Rao, "Design and integration of solar-biomass hybrid energy system for drip irrigation pumping,” J. Chem. Pharm. Sci., vol. 2014-Decem, no. August 2012, pp. 247-248, 2014.

[16] M. S. Adaramola, M. Agelin-Chaab, and S. S. Paul, “Analysis of hybrid energy systems for application in southern Ghana,” Energy Convers. Manag., vol. 88, no. 2014, pp. 284-295, 2014, doi: 10.1016/j.enconman.2014.08.029.

[17] D. T. Cotfas, P. A. Cotfas, E. Kaplani, and C. Samoila, "Monthly average daily global and diffuse solar radiation based on sunshine duration and clearness index for Brasov, Romania," J. Renew. Sustain. Energy, vol. 6, no. 5, 2014, doi: 10.1063/1.4896596.

[18] I. B. Askari and M. Ameri, "Techno-economic feasibility analysis of stand-alone renewable energy systems (PV/bat, wind/bat and hybrid PV/wind/bat) in Kerman, Iran,” Energy Sources, Part B Econ. Plan. Policy, vol. 7, no. 1, pp. 45-60, 2012, doi: 10.1080/15567240903330384.

[19] D. Akinyele, J. Belikov, and Y. Levron, "Challenges of microgrids in remote communities: A STEEP model application,” Energies, vol. 11, no. 2, pp. 1-35, 2018, doi: 10.3390/en11020432. 